\title{
PEMBENTUKAN USAHAWAN KRAF TANGAN WANITA DI \\ MALAYSIA: PERANAN SIKAP, WARISAN KELUARGA DAN PEMBUDAYAAN NILAI AGAMA
}

\section{THE FORMATION OF HANDICRAFT WOMEN ENTREPRENEURS IN MALAYSIA: THE ROLES OF ATTITUDES, FAMILY HERITAGE AND RELIGIOUS VALUES}

\section{Nor Hanim Awang@ Mohd Noor ${ }^{1}$, Norfatiha Othman ${ }^{1 *}$ and Nor Hayati Sa' $^{\prime} \mathbf{t}^{1,2}$}

${ }^{1}$ Faculty of Business, Economics and Social Development, Universiti Malaysia Terengganu, Terengganu, MALAYSIA

${ }^{2}$ Institute of Tropical Biodiversity and Sustainable Development, Universiti Malaysia Terengganu, Terengganu, MALAYSIA

"Corresponding author: fatiha.nfo@gmail.com

Published online: 29 October 2021

To cite this article: Nor Hanim Awang @ Mohd Noor, Norfatiha Othman and Nor Hayati Sa'at. 2021. Pembentukan usahawan kraf tangan wanita di Malaysia: Peranan sikap, warisan keluarga dan pembudayaan nilai agama. Kajian Malaysia 39(2): 153-178. https://doi.org/10.21315/ $\mathrm{km} 2021.39 .2 .7$

To link to this article: https://doi.org/10.21315/km2021.39.2.7

\begin{abstract}
The participation of women in entrepreneurship plays a significant role in economic development especially in reducing unemployment, increasing production and consumption, achieving gender equality, social and cultural reforms. One of the dominant areas for women is batik and songket entrepreneurs who are synonymous with women on the East Coast of Peninsular Malaysia. Studies have identified three key elements that contribute to the development of this craft entrepreneur, viz. attitude, business inheritance and religious value culture. Qualitative design methods based on case studies and in-depth interviews were used in this study on 12 informants in the state of Kelantan and Terengganu in Malaysia. The findings show that there are three main factors that cause the formation of women handicraft entrepreneurs, namely attitude, family heritage and religious values. Hence, all the factors that make up a female handicraft entrepreneur in Malaysia are discussed in this article.
\end{abstract}


The findings imply that increasing women entrepreneurs in handicrafts can raise the quality of handicraft products into becoming the best tourism products in the East Coast.

Keywords: attitudes, family heritage, religious values, handicraft women entrepreneur

\begin{abstract}
ABSTRAK
Penyertaan wanita dalam bidang keusahawanan memainkan peranan yang signifikan dalam pembangunan ekonomi khususnya dalam mengurangkan kadar pengangguran, meningkatkan tahap pengeluaran dan penggunaan, pencapaian kesaksamaan gender, sosial dan budaya. Salah satu bidang keusahawanan yang dominan dengan wanita ialah usahawan kraf batik dan songket yang sinonim dengan wanita di pantai Timur, Semenanjung Malaysia. Kaedah reka bentuk kualitatif berasaskan kajian kes dan temu bual mendalam yang digunakan dalam kajian ini dilakukan ke atas 12 orang informan di negeri Kelantan dan Terengganu di Malaysia. Hasil kajian ini menunjukkan terdapat tiga faktor utama yang menyebabkan pembentukan usahawan kraf tangan wanita iaitu sikap, warisan keluarga dan pembudayaan nilai agama. Oleh itu, semua faktor yang membentuk usahawan kraf tangan wanita di Malaysia dibincangkan dalam makalah ini. Implikasinya, peningkatan usahawan wanita dalam bidang kraf tangan dapat menjadikan produk kraf tangan sebagai produk pelancongan yang terbaik di pantai Timur.
\end{abstract}

Kata kunci: sikap, warisan keluarga, nilai agama, usahawan kraf tangan wanita

\title{
PENGENALAN
}

Senario pembangunan negara menekan kaum wanita untuk menceburi bidang keusahawanan. Kini, wanita menyumbang dan mendokong ekonomi negara secara tidak langsung di pelbagai sektor (Kalpana 2016), salah satunya sektor pembuatan kraf tangan. Tekanan ini menuntut mereka menggerakkan sesuatu aktiviti ekonomi dan memiliki ciri-ciri keusahawanan tertentu. Antaranya, berdaya saing dan memiliki daya tahan yang tinggi, sentiasa mencari peluang, kreatif, inovatif dan berkemampuan untuk menjalankan aktiviti ekonomi tersebut dengan kemungkinan berhadapan pelbagai risiko. Selari dengan pandangan Ibnu Khaldun (1904), seorang usahawan ialah individu yang mempunyai inisiatif untuk memaksimumkan kecekapan dan tahap pengeluaran melalui aktiviti 
perniagaan untuk mendapatkan keuntungan. Mereka memiliki kebolehan untuk menjadikan dan menghubungkan matlamat tertentu secara sistematik dalam ekonomi melalui pencapaian dan wawasan yang dimiliki (Scott 2000). Seseorang usahawan dapat mengenal pasti dan mencipta peluang untuk menghasilkan pergerakan komoditi yang baik, teknik yang baru (inovasi) serta mengurus sumber alam berasaskan penggunaan faktor pengeluaran yang terhad untuk membangunkan kekayaan melalui proses tambah nilai terhadap sumber tersebut (Drucker 1964; Kirzner 1979; Jhingam 1979). Dengan kata lain, usahawan perlu kreatif dan mampu mengorganisasikan serta mengurus sesuatu perusahaan sehingga berjaya.

Usahawan kraf tangan merujuk kepada seseorang yang menjalankan urus niaga berkaitan produk buatan tangan (handmade) yang mempunyai daya tarikan budaya dan artistik (Noor Fzlinda et al. 2014). Sedangkan Rogerson (2010) menganggap produk kraf mestilah dihasilkan melalui $80 \%$ buatan tangan termasuk pelbagai material seperti fiber, tekstil, tanah liat dan produk kitar semula. Perkembangan perusahaan kraf tangan di Malaysia dipercayai berasal daripada pendatang yang kebanyakannya merupakan pedagang. Pedagangpedagang dari Jawa, Kepulauan Maluku, Borneo dan Bugis telah memperkenalkan beberapa jenis kain tenunan. Beberapa corak tenunan yang dihasilkan di Kelantan dan Terengganu misalnya diberi nama seperti tempat asal pedagang-pedagang tersebut (Siti Zainon 1986, 176). Negeri-negeri utama yang terkenal dalam menghasilkan tenunan di Malaysia ialah Kelantan, Terengganu dan Pahang (Siti Zainon 1986, 173). Namun, penghasilan kraf tangan batik dan songket lebih terkenal di pantai Timur iaitu di Kelantan (batik) dan Terengganu (songket) dalam kalangan golongan wanitanya yang aktif dalam aktiviti ekonomi seperti perniagaan. Golongan wanita lebih mendominasi aktiviti jual beli di pasar mahupun di tempat perniagaan. Berasaskan kepada perspektif sejarah dan tradisi, wanita di Malaysia dikatakan sudah lama menceburkan diri dalam dunia perniagaan dan menjadi usahawan (Nor Aini 2003).

Sejarah awal penglibatan wanita Melayu dalam perniagaan kraf tangan terutama di Kelantan dan Terengganu bermula di pasar (Laderman 1982). Penglibatan wanita dalam bidang perniagaan bukanlah sesuatu yang baharu. Pada 1400 tahun dahulu, Sayyidatina Khatijah telah terkenal sebagai seorang usahawan wanita yang berjaya sebelum berkahwin dengan Nabi Muhammad SAW lagi. Aktiviti perniagaan yang diusahakan beliau merentasi sempadan negeri sehingga ke peringkat antarabangsa dan menjadi contoh usahawan wanita terbaik bagi wanita yang berminat dalam bidang keusahawanan (Syarifah et al. 2018, 3). 
Maklumat daripada Perbadanan Kraftangan Malaysia di Kelantan dan Terengganu menunjukkan wanita mendominasi dalam perusahaan kraf tangan batik dan songket. Statistik menunjukkan sehingga tahun 2015, terdapat sejumlah 130 orang wanita di daerah Kota Bharu dan 371 orang wanita di daerah Kuala Terengganu yang terlibat dalam perusahaan kraf tangan. Daripada jumlah tersebut, terdapat 128 orang wanita di daerah Kota Bharu dan 330 orang wanita di daerah Kuala Terengganu yang terlibat dalam perusahaan batik dan songket. Di antara kajian yang mengetengahkan penglibatan usahawan wanita dalam perniagaan kraf tangan berasaskan batik dan songket ialah Haziyah (2006b) yang melakukan kajian di Semenanjung Malaysia dan mendapati bahawa aktiviti perusahaan kraf tangan ini merupakan aktiviti keluarga. Berdasarkan aspek sejarah tekstil khususnya aktiviti menenun kain, aktiviti ini merupakan satu aktiviti yang penting dalam kalangan pemerintah sebelumnya seperti dilakukan oleh Cik Siti Wan Kembang. Cik Siti Wan Kembang merupakan pemerintah di Kelantan pada abad ke-17 telah memberi galakan kepada setiap wanita untuk menceburi aktiviti menenun dan membatik bagi kegunaan sendiri dan juga golongan istana sehingga menjadi kemestian bagi wanita. Manakala kajian Norwani (1994) pula tentang perusahaan songket di Malaysia mendapati golongan wanita pada zaman dahulu mempunyai kemahiran sebagai tukang tenun songket sehingga dapat bekerja dengan golongan istana dan bangsawan. Golongan gadis yang belum berkahwin pula diwajibkan untuk mempelajari aktiviti menenun songket sehingga mereka meningkat dewasa. Aktiviti menenun songket ini menjadi penanda aras kepada tahap kemahiran seorang wanita Melayu bagi menggambarkan kesempurnaan yang ada dalam diri mereka.

Mohd Shaladdin dan Muhammad Abi Sofian (2011) turut membincangkan tentang usahawan kraf tangan di Malaysia yang menumpukan kepada analisis laluan terhadap perhubungan inovasi produk, komitmen perniagaan dan perkembangan perniagaan. Seramai 380 orang daripada 1,347 orang usahawan kraf tangan yang beroperasi di bawah Perbadanan Kemajuan Kraftangan Malaysia telah menjadi responden kajian. Dapatan kajian menunjukkan faktorfaktor di bawah inovasi produk mempunyai perhubungan yang signifikan dengan komitmen perniagaan. Faktor komitmen perniagaan juga menunjukkan nilai yang signifikan terhadap perhubungan dengan perkembangan perniagaan. Kajian lain yang mengetengahkan tentang perniagaan kraf tangan seperti yang ditulis oleh Norazilawati dan Arba'iyah (2013) yang bertujuan menganalisis pencapaian masyarakat Melayu dalam aktiviti perindustrian di Terengganu dari tahun 1800 hingga 1941. Mereka menyimpulkan bahawa pada abad ke-19 dan ke-20, Terengganu telah mengalami proses perkembangan perusahaan yang sangat penting. Jangka masa tersebut memperlihatkan perubahan ekonomi mula berlaku daripada ekonomi berbentuk tradisional kepada ekonomi yang berbentuk 
komersial. Aktiviti perusahaan yang berasaskan produk tradisional berjaya membuktikan produk tempatan asli dapat dipasarkan ke peringkat antarabangsa selain menambat hati masyarakat di seluruh Tanah Melayu yang sememangnya menghargai produk Melayu warisan zaman silam. Selain itu, terdapat juga kajian yang melihat kepada perkembangan industri kraf tangan dan kesannya kepada ekonomi di Kelantan (Nik Azma 2015). Kajian Nik Azma mendapati industri kraf tangan di Kelantan banyak membuka peluang pekerjaan, meningkatkan pendapatan isi rumah dan menyumbang kepada perkembangan ekonomi negeri. Selain itu, kajian lain yang melibatkan usahawan kraf tangan wanita dilaporkan oleh Zaimah dan Sazuani (2017) yang meneliti tentang tahap keupayaan usahawan dalam perusahaan kecil dan sederhana di Kuala Terengganu. Di antara perusahaan kecil dan sederhana yang diberi perhatian dalam kajian mereka ialah makanan, kraf tangan, batik, songket dan lain-lain. Hasil kajian mereka mendapati tahap keupayaan kepimpinan peribadi dan keupayaan kemahiran pengurusan usahawan berada pada tahap sederhana tinggi manakala tahap keupayaan proaktif usahawan pula berada pada tahap tinggi. Menyedari tentang kepentingan peranan budaya yang berupaya membentuk usahawan batik dan songket wanita di pantai Timur, makalah ini bertujuan untuk menganalisis pembentukan usahawan kraf tangan wanita di Malaysia dengan menumpukan kepada peranan sikap, warisan keluarga dan pembudayaan nilai agama sebagai faktor pembentukan tersebut.

Pembentukan usahawan kraf tangan dalam kajian ini bermaksud usaha atau perbuatan yang menjadikan seseorang individu menjadi usahawan. Terdapat unsur tertentu yang menyumbang kepada usaha pembentukan usahawan wanita iaitu peranan sikap usahawan tersebut, pewarisan perniagaan daripada keluarga dan penerapan nilai agama. Perkara umum ini menjawab tiga soalan khusus iaitu:

1. Apakah sikap yang perlu dimiliki oleh usahawan wanita apabila menceburi bidang perniagaan?

2. Bagaimanakah perniagaan warisan keluarga mempengaruhi penglibatan wanita dalam perniagaan?

3. Sejauh manakah pembudayaan nilai agama berpotensi menggerakkan keusahawanan wanita?

Persoalan ini dapat menghuraikan tentang penyumbang utama kepada pembentukan usahawan wanita batik terutamanya dalam aspek gender itu sendiri. Perkembangan mengenai kajian gender iaitu usahawan wanita dan perusahaan kraf tangan secara tidak langsung menambah korpus ilmu sosiologi gender khususnya dalam masyarakat yang secara signifikannya memberi kesan kepada 
proses pengeluaran, penggunaan dan pengagihan terutama dalam bidang ekonomi. Walaupun kajian ke atas keusahawanan wanita di Malaysia meluas, tetapi kajian khusus yang mengaitkan faktor sikap, warisan keluarga dan pembudayaan nilai agama sebagai penggerak kepada pembentukan usahawan kraf tangan wanita masih kurang diberi penekanan. Untuk tujuan tersebut, kajian ini berusaha untuk meneroka bagaimana peranan sikap, warisan keluarga dan pembudayaan nilai agama dalam membentuk usahawan kraf tangan wanita di Malaysia.

\section{SOROTAN KAJIAN}

Kajian ini dilakukan bertujuan untuk mengenal pasti faktor-faktor yang membentuk usahawan kraf tangan wanita di Malaysia yang berasaskan kepada peranan sikap, warisan keluarga dan pembudayaan nilai agama. Sehingga kini, aktiviti keusahawanan wanita telah berjaya menarik perhatian ramai pengkaji dalam pelbagai bidang untuk merungkai pelbagai persoalan. Azlizan et al. (2017) misalnya, memfokuskan kepada wanita dan perniagaan atas talian sebagai pemangkin penyertaan kaum wanita dalam keusahawanan di luar bandar. Penemuan kajian menunjukkan perniagaan atas talian memberi implikasi positif dalam mempengaruhi cara hidup masyarakat iaitu menjimatkan masa pengguna dan turut memberi implikasi negatif dengan mengurangkan interaksi sosial dalam kalangan masyarakat. Peranan faktor motivasi terhadap usahawan wanita menjadi tumpuan Ivana, Jelena dan Ana (2017) yang bertujuan untuk menentukan bagaimana motivasi berperanan kepada keputusan yang diambil oleh wanita untuk menjadi usahawan pada masa depan. Hasil kajian mereka menunjukkan bahawa wanita dimotivasikan oleh aspek kewangan iaitu keuntungan yang bakal mereka peroleh sekiranya menceburi bidang keusahawanan seterusnya menjadi alasan ingin menjadi usahawan. Sementara itu, kajian Zurinah et al. (2019) menganalisis transformasi memajukan industri kecil dan sederhana dalam kalangan wanita luar bandar. Kajian mereka mendapati strategi "mencari peluang yang ada" dan "berusaha" untuk meningkatkan perniagaan adalah amat penting dalam kalangan wanita luar bandar untuk memajukan sektor industri kecil dan sederhana. Strategi ini memberi ruang kepada golongan wanita daripada pelbagai latar belakang untuk perkongsian idea, pengalaman serta aspirasi dan secara tidak langsung mempromosikan produk sama ada di peringkat tempatan mahupun peringkat global (Zurinah et al. 2019).

Penggunaan internet dalam kalangan usahawan wanita seperti kajian Faradillah, Samsudin dan Nur Ajeerah (2017) yang bertujuan untuk mengetahui pola penggunaan internet dalam kalangan usahawan wanita dengan dimensi-dimensi 
yang telah dikenal pasti. Hasil dapatan kajian mereka menunjukkan aplikasi yang sering diakses dan digunakan ialah aplikasi yang menjadi perhatian ramai seperti WhatsApp, Facebook dan Instagram dalam kadar yang tinggi. Prestasi pengusaha wanita berasaskan faktor modal insan dan daya saing seperti dilakukan oleh Nor Azira, Sity dan Nurul Nadia (2018) mendapati terdapat empat faktor utama yang menyumbang kepada pembangunan modal insan dalam kalangan usahawan wanita bumiputera iaitu pendidikan dan latihan, pengalaman, sokongan sosial dan kreativiti, di samping tiga faktor utama yang menyumbang kepada daya saing dalam kalangan usahawan iaitu bantuan kewangan, prasarana dan infrastruktur, dan iltizam perniagaan. Amalan gaya hidup Islam dalam kalangan usahawan wanita Muslim berjaya pula menjadi tumpuan Syarifah et al. (2018). Kajian mereka bertujuan untuk meneroka amalan gaya hidup Islam berdasarkan ciri-ciri keimanan, ibadah dan akhlak yang diamalkan oleh usahawan wanita Muslim berjaya. Penemuan kajian mereka menunjukkan usahawan wanita Muslim berjaya meyakini konsep keberkatan rezeki, rezeki ketentuan Allah dan berdoa. Manakala elemen ibadah yang diamalkan oleh mereka melibatkan zakat, sedekah, solat dhuha, membaca al-Quran dan hubungan silaturahim. Elemen akhlak pula menunjukkan sifat syukur, tawakal, sabar dan pemurah menjadi amalan usahawan wanita Muslim berjaya (Syarifah et al. 2018).

Kajian terhadap usahawan wanita Felcra Berhad oleh Mohd Maliki dan Norasmah (2018) bertujuan untuk meneroka amalan pengurusan perniagaan usahawan wanita Felcra Berhad dalam aspek pemasaran, sumber manusia dan kewangan. Penerokaan dibuat berdasarkan faktor demografi seperti pengalaman, minat, sumber pendapatan dan latar belakang keluarga, selain meneroka prestasi perniagaan usahawan wanita dan saiz perniagaan, kewangan perniagaan dan bilangan pekerja. Hasil kajian Mohd Maliki dan Norasmah (2018) mendapati faktor demografi seperti minat dan sumber pendapatan menjadi pendorong penglibatan usahawan wanita Felcra Berhad dalam bidang keusahawanan. Selain itu, mereka turut mendapati usahawan wanita menggunakan teknologi terkini dalam aspek pengurusan pemasaran dan memiliki pekerja yang mencukupi bagi keperluan perniagaan serta mempunyai kemudahan kredit dengan pembekal bagi memperoleh bahan mentah (Mohd Maliki dan Norasmah 2018). Peranan dan pelaksanaan ICT dalam kajian Siti Masayu Rosliah dan Narimah (2019) bertujuan untuk menganalisis peranan dan keupayaan internet dalam usaha membantu dan memperkasakan usahawan wanita luar bandar untuk meningkatkan sosio-ekonomi masing-masing. Hasil kajian menunjukkan $90.8 \%$ responden menganggap internet memainkan peranan penting dalam usaha meningkatkan pendapatan bulanan wanita luar bandar. Namun begitu, penggunaannya masih rendah disebabkan oleh kekurangan capaian, kemahiran, 
lokasi, perubahan gaya hidup dan soal individu yang masih mengekang penggunaannya (Siti Masayu Rosliah dan Narimah 2019).

Nsubili (2019) dalam kajiannya mengenai usahawan wanita bertujuan untuk mengenal pasti motif wanita di Tanzania (negara yang kurang maju) untuk memulakan perniagaan sendiri dan cabaran yang mereka hadapi dalam menjalankan perniagaan. Hasil daripada kajian Nsubili menunjukkan alasan utama wanita memulakan perniagaan adalah untuk mencipta pekerjaan untuk wanita itu sendiri. Motif lain termasuklah menambah pendapatan dan membolehkan wanita dapat melakukan jenis pekerjaan yang diingini. Masalah yang sering dihadapi oleh usahawan wanita adalah kurangnya akses kepada kewangan, masalah berkaitan jantina dan komitmen sosial dan budaya. Keusahawanan wanita dan hubungannya dengan inovasi pula diteliti oleh Jyoti (2019) yang bertujuan meneroka perkaitan keusahawanan wanita dan inovasi berdasarkan ciri-ciri peribadi dan perniagaan usahawan wanita. Hasil kajian mendapati inovasi keusahawanan wanita sangat dipengaruhi oleh faktor umur dan pendidikan wanita, dan jenis, lokasi serta saiz perniagaan.

Terdapat beberapa tumpuan kajian yang dilakukan oleh sarjana lalu misalnya faktor penglibatan wanita dalam keusahawanan, peranan motivasi, perusahaan kecil dan pengurusan dalam aktiviti keusahawanan, penggunaan internet oleh usahawan wanita, motif penglibatan dalam keusahawanan, prestasi usahawan wanita dan amalan keusahawanan menurut Islam. Justeru, bersesuaianlah makalah ini mengkaji mengenai faktor pembentukan usahawan kraf tangan wanita iaitu sikap, warisan keluarga dan pembudayaan nilai agama.

\section{KAEDAH KAJIAN}

Kajian ini menggunakan pendekatan kualitatif khususnya reka bentuk kajian kes kualitatif untuk menganalisis pembentukan usahawan kraf tangan wanita di Malaysia khususnya di negeri Kelantan dan Terengganu. Kajian kes kualitatif merupakan penerokaan secara mendalam ke atas satu sistem yang terbatas seperti aktiviti, proses, individu ataupun acara. Sistem yang terbatas ini bermaksud kajian kes yang dilakukan untuk tujuan penyelidikan dari segi masa, tempat atau beberapa sempadan fizikal (Creswell dan Clark 2007). Seramai 12 orang informan terlibat dalam kajian ini yang melibatkan enam orang usahawan kraf tangan di Kelantan dan enam orang di Terengganu ditemu bual secara mendalam. Pemilihan 12 orang informan berdasarkan tiga pertimbangan. Pertama, temu bual telah mencapai titik tepu dalam proses pengumpulan data iaitu informan berikutnya memberi jawapan yang sama seperti sebelumnya. 
Kedua, informan yang dipilih telah menjalankan perniagaan lebih daripada lima tahun, memiliki premis perniagaan persendirian dan menghasilkan produknya sendiri untuk dipasarkan. Ketiga, kajian juga mengambil kira kerjasama yang diberikan oleh informan yang secara sukarela untuk ditemu bual dan kajian akan memilih informan lain sekiranya mereka tidak ingin memberikan kerjasama.

Temu bual mendalam ini dilakukan secara terbuka yang berdurasi 10 jam 10 minit dengan tujuan untuk mendapatkan maklumat yang dikehendaki bagi melengkapi objektif kajian. Soalan-soalan temu bual ini akan ditentukan terlebih dahulu tetapi jawapan kepada soalan-soalan tersebut bersifat terbuka dan boleh dikembangkan mengikut budi bicara pengkaji dan informan kajian. Hasil temu bual ditranskripsikan kepada data verbatim untuk dianalisis menggunakan kaedah analisis secara tematik. Kaedah analisis data secara tematik dibahagikan kepada enam fasa iaitu, (1) menyusun atur data; (2) menjana kategori, tema dan pola; (3) mengekod data; (4) menguji kefahaman yang timbul; (5) mencari penerangan alternatif; dan (6) menulis laporan (Marshall dan Rossman 1999). Hasil analisis kajian memperoleh tiga tema utama dan sembilan sub-tema dalam konteks pembentukan usahawan kraf tangan wanita iaitu (1) sikap (sub-tema: merebut peluang, semangat keusahawanan dan layanan); (2) warisan keluarga (sub-tema: budaya warisan, situasi semasa dan pendedahan dalam perniagaan); dan (3) pembudayaan nilai agama (sub-tema: sunnah, peluang bersedekah dan membina hubungan silaturahim).

\section{HASIL KAJIAN DAN PERBINCANGAN}

Informan yang ditemu bual berumur dalam lingkungan umur 27 hingga 56 tahun. Kesemua informan terdiri daripada lima orang yang menjalankan perniagaan kraf tangan songket dan tujuh orang dalam perniagaan kraf tangan batik. Tahap pendidikan informan meliputi dua orang berkelulusan Penilaian Menengah Rendah (PMR), enam orang berkelulusan Sijil Pelajaran Malaysia (SPM), seorang berkelulusan Sijil Tinggi Pelajaran Malaysia (STPM), seorang berkelulusan sijil/diploma dan dua orang berkelulusan ijazah. Tempoh informan kajian telah memulakan perniagaan masing-masing di antara 7 hingga 37 tahun. Dari segi asal usul perniagaan informan pula, terdapat informan yang ditemui meneruskan perniagaan warisan daripada generasi sebelumnya iaitu, daripada ibu dan bapa mentua mereka. Informan yang mewarisi perniagaan daripada ibu berjumlah tujuh orang manakala dua orang informan mewarisi perniagaan daripada bapa mentua manakala informan yang memulakan perniagaan baru diusahakan sendiri pula seramai tiga orang. Berdasarkan kepada hasil kajian yang diperoleh menunjukkan terdapat tiga peranan yang menjadi faktor kepada 
pembentukan usahawan kraf tangan wanita iaitu, sikap, warisan keluarga dan pembudayaan nilai agama. Ketiga-tiga peranan ini menjadi penunjuk penting kepada keterlibatan golongan wanita dalam industri kraf tangan di Malaysia.

\section{Sikap}

Sikap dalam konteks usahawan kraf tangan wanita merupakan tindakan yang dilakukan dalam sesuatu perkara untuk memuaskan diri sendiri bagi mendapatkan atau mencapai matlamat yang diinginkan. Terdapat tiga elemen peranan sikap yang ada pada diri informan iaitu merebut peluang dalam perniagaan, semangat keusahawanan dan layanan yang diberikan terhadap pelanggan.

\section{Merebut peluang perniagaan}

Sikap merebut peluang merupakan salah satu ciri keusahawanan yang penting dalam sesebuah perusahaan yang diceburi. Maksud merebut peluang dalam erti kata kajian ini ialah merebut peluang terlibat dalam bidang batik dan songket dari ahli keluarga, dan peluang untuk meluaskan perniagaan. Penerokaan peluang yang sedia ada dalam ahli keluarga memberi peluang kepada wanita-wanita yang pada asalnya merupakan seorang suri rumah untuk berusaha menambah sumber kewangan dan perbelanjaan keluarga mereka. Sementelahan wanita yang sudah terlibat dalam perusahaan ini akan cuba meneroka peluang untuk meluas, mengembang dan memperkenalkan produk mereka kepada orang luar. Menurut Puan $\mathrm{Na}$ yang telah mengusahakan perniagaan batik selama lebih 28 tahun menyatakan bahawa:

Dale (dalam) dunio perniagaan ni banyok cabaran dio...ado pasang surutnya...lebih-lebih dale nego (berniaga) ni...jadi kite keno ado strategi nak mengembangkan perniagaan hok sedio ada...gapo hok saye buat...saye bukok dua cawangan perniagaan bergerak...duduk di Kuala Lumpur...tu suami saye hok handle...kalu ada perhimpunan Agung UMNO ko, suami akan gi (pergi) nego sana...kadang-kadang event hok Perbadanan Kemajuan Kraftangan Malaysia buat pun saye join... mace hok saye kata tadi la, kite sebagai peniaga ni keno ambil tahu semo (semua) peluang hok ada...di pasar malam pun saye ambil peluang nego setiap minggu. (Kajian lapangan pada 2015 bersama Puan Na)

Walaupun dunia perniagaan mempunyai cabaran dan risiko tinggi, setiap peluang yang ada perlu digunakan dengan sebaiknya untuk mencapai wawasan yang diinginkan. Usahawan wanita juga perlu mempunyai strategi keusahawanan bagi meningkatkan keuntungan perusahaan yang sedang dijalankan. Hal ini menunjukkan walaupun telah berjaya dalam perniagaan yang diceburi, mereka 
tidak sesekali mengambil mudah dengan situasi yang selesa. Mereka perlu sentiasa mencari peluang dengan berniaga di pasar-pasar malam walaupun telah mempunyai cawangan perniagaan yang lain.

\section{Semangat keusahawanan}

Selain itu, semangat keusahawanan merupakan keinginan yang tinggi bagi mencapai cita-cita menjadi usahawan wanita yang berjaya. Keinginan yang tinggi dapat mencungkil sifat yakin dengan keupayaan diri sendiri untuk mengusahakan sesebuah perniagaan. Aktiviti keusahawanan merupakan pekerjaan yang perlu berhadapan dengan risiko yang tinggi menyebabkan usahawan wanita perlu bersaing dengan usahawan lelaki bagi mencari peluang-peluang perniagaan yang boleh memajukan perniagaan yang diusahakan. Walaupun bidang keusahawanan merupakan suatu pekerjaan yang dijalankan tanpa pendapatan yang tetap pada setiap bulan, namun bidang ini memberi kepuasan kepada usahawan wanita. Mereka beranggapan bidang keusahawanan lebih memberi kepuasan yang tinggi jika dibandingkan dengan melakukan pekerjaan yang berpendapatan tetap. Elemen semangat keusahawanan ini ditonjolkan oleh Puan Non iaitu:

Saya pandai nego (berniaga) sebab belajar dari mok (mak)...mok dulu mula nego...meme (memang) dari dulu saya tak suka kijo (kerja) denge ore (orang)...tak bebas raso. Kijo sendiri tak terikat sangat laa... kiranya saya ni generasi kedua lah hok nego dale keluarga lepas mok. (Kajian lapangan pada 2015 bersama Puan Non)

Berdasarkan pandangan informan tersebut, semangat keusahawanan menjadi penanda aras kepada pembentukan usahawan wanita. Pengaruh semangat keusahawanan ini ditunjukkan melalui kecenderungan keusahawanan yang tinggi dalam diri wanita selain mendapat kepuasan dalam pekerjaan yang diceburi. Hasilnya, golongan wanita tidak teragak-agak untuk memulakan langkah dengan menubuhkan perniagaan sendiri bagi merealisasikan keinginan diri mereka untuk menjadi usahawan wanita.

\section{Layanan}

Seterusnya, layanan dalam konteks sikap merupakan etika yang diamalkan usahawan ke atas pelanggan semasa mengusahakan perniagaan. Etika yang diamalkan dalam kajian ini ialah keutamaan yang diberikan kepada pelanggan dalam aspek pemilihan produk yang diinginkan pelanggan. Layanan baik yang diberikan akan memberi keselesaan kepada pelanggan dalam proses jual beli 
yang dilakukan. Keadaan ini dapat meningkatkan keuntungan yang diterima ke atas usahawan wanita yang mengusahakan perniagaan dan menggalakkan penglibatan wanita lain untuk turut serta dalam aktiviti keusahawanan. Aspek layanan ditunjukkan seperti yang dinyatakan oleh Puan Mas seperti berikut:

Saya ni lamo doh nego (berniaga) batik ni...dah 37 tahun doh...macemace (macam-macam) jenis pelanggan doh hok jupe (jumpa). Kalu (kalau) ada pelanggan masuk kedai...meme (memang) saya layan molekmolek...tunjuk corak hok dio nak. Biasonya pelanggan hok sama akan mari balik ke kedai....bawok (bawa) pulak orang lain. (Kajian lapangan pada 2015 bersama Puan Mas)

Elemen layanan dalam konteks sikap merupakan asas kepada pembentukan usahawan kraf tangan wanita. Layanan bermula dengan cara seorang usahawan berinteraksi dengan pelanggan mereka ketika melakukan proses jual beli. Proses jual beli dalam perniagaan memerlukan etika yang betul bagi menarik perhatian pembeli. Hal ini kerana golongan wanita berkebolehan mencari sumber pendapatan tambahan keluarga, maka tidak hairanlah mengapa terdapat ramai wanita menceburi aktiviti keusahawanan. Oleh itu, usahawan perlu mempunyai sikap untuk maju tanpa hanya mengharapkan bantuan daripada pihak kerajaan semata-mata bagi membolehkan mereka bersaing dalam pasaran yang semakin mencabar. Perkara ini selari dengan konsep keusahawanan yang memerlukan ciri-ciri seperti kebolehan, kemampuan dan kecenderungan untuk mencari, mengenal dan merebut peluang perniagaan tanpa hanya melihat dan membiarkan peluang tersebut hilang. Seseorang usahawan yang ingin berjaya seharusnya mempunyai daya saing yang tinggi, kreatif dan inovatif serta mempunyai iltizam perniagaan yang tinggi dalam menghasilkan barangan atau perkhidmatan yang memenuhi kehendak pelanggan dan pasaran (Nor Azira, Sity dan Muhamad Takiyuddin 2016, 58).

\section{Warisan Keluarga}

Wanita yang dilahirkan dalam keluarga yang mengusahakan perniagaan warisan keluarga lebih banyak terdedah dengan aktiviti keusahawanan sejak dari awal kehidupan. Mereka dapat mengetahui tugas dan peranan pengasas perniagaan sebelum ini untuk mengembangkan perniagaan tersebut. Selain itu juga, keusahawanan batik dan songket begitu sinonim dengan golongan wanita. Oleh itu, individu yang dilahirkan dalam keluarga yang terlibat dalam keusahawanan dianggap lebih berpengalaman berbanding dengan mereka yang memulakan perniagaan sendiri. Perbincangan warisan keluarga dalam kajian ini berdasarkan kepada tiga aspek iaitu budaya warisan, situasi semasa dan pendedahan dalam perniagaan. 


\title{
Budaya warisan
}

Budaya warisan keluarga merupakan amalan berniaga yang dipindahkan dari satu generasi ke generasi yang lain. Wanita yang mempunyai sejarah perniagaan di dalam keluarga sama ada ibu ataupun bapa akan menunjukkan ciri-ciri yang sama seperti pewaris mereka. Budaya keusahawanan yang diamalkan telah sebati dalam sesebuah keluarga dan dianggap sebagai punca pendapatan yang utama. Perniagaan yang menjadi nadi warisan keluarga sejak beberapa generasi secara tidak langsung menjadi ikutan kepada generasi seterusnya. Perniagaan warisan keluarga yang bermula sejak beberapa generasi merupakan alasan wanita melibatkan diri dalam kegiatan keusahawanan bagi mengekalkan budaya berniaga dalam keluarga. Mengekalkan budaya berniaga juga membolehkan perusahaan keluarga yang ditubuhkan oleh pengasas perniagaan dapat bertahan dalam jangka masa yang lama. Menurut Puan Tom, pada masa dahulu, aktiviti menyongket dan menenun sangat aktif di tempat kelahirannya iaitu di Chendering, Kuala Terengganu.

\begin{abstract}
Dulu masa kecik-kecik, masa balik sekolah...masa tu sekolah menengah agi (dale umur 14 tahun tu), selalu tengok mok nenun (pintal benang), nyongket (membuat bunga di kain songket). Hari-hari tengok gitu (aktiviti ibunya menenun/menyongket) sampai saye pun nok try buat mace mok buat. Bila dah buat, jadi minat nak buat sebagai kije (kerja)... nak bukak kedai sendiri. Sampai umur sekarang (tahun 2015)... saye masih dok urus perniagaan ni dibantu anak-anak laa....tulah rasa sayang nak tinggal sebab...aktiviti ni mula lamo dah...sejak zaman arwah nenek lagi...lepas tu arwah mok saye pulok...ni saye nok kekalkan budaya nego (berniaga) dale keluarga ni. (Kajian lapangan pada 2015 bersama Puan Tom)
\end{abstract}

Kebanyakan usahawan wanita ini mahu mengekalkan budaya berniaga dalam keluarga yang bermula sejak dua generasi sebagai alasan pembabitan mereka. Ketika berada di bangku sekolah, informan telah melihat ibu beliau melakukan aktiviti menenun songket di rumah. Sejak itu, timbul minat dengan aktiviti tenunan songket dan ingin meneruskan budaya berniaga yang telah sebati dalam keluarga. Di samping itu, adik-beradik (terutamanya perempuan) turut terlibat dalam aktiviti tenunan songket sehingga sekarang.

Terdapat juga wanita yang dilahirkan daripada generasi kedua dalam keluarga mereka turut menjadikan keusahawanan sebagai pekerjaan mereka. Mereka menceburi aktiviti keusahawanan bukan sahaja untuk mengisi masa lapang tetapi meneruskan perniagaan warisan keluarga. Oleh yang demikian, selagi ada legasi keluarga yang meneruskan kesinambungan budaya berniaga ini, 
selagi itulah budaya berniaga dalam sesebuah keluarga akan sentiasa berterusan. Terdapat wanita yang mengorak langkah sebagai usahawan untuk meneruskan perniagaan warisan keluarga dari satu generasi ke generasi seterusnya. Budaya berniaga yang tertanam melalui perniagaan keluarga merupakan punca yang mempengaruhi Puan Idah menceburi bidang keusahawanan.
Penglibatan saya dale (dalam) aktiviti keusahawanan ni buke (bukan) hanyo nok isi masa lapang ataupun nok suka-suka, tapi nok teruskan perniagaan warisan keluarga hok mok bukok (buka) dulu...supaya buleh bertahan lamo sikit ko anok cucu...nok capai cita-cita nok jadi peniaga srupo (seperti) mok. (Kajian lapangan pada 2015 bersama Puan Idah)

Budaya warisan yang berasaskan tema warisan keluarga menunjukkan penglibatan dalam keusahawanan bukan dilakukan bagi mengisi masa lapang, tetapi ingin meneruskan perniagaan warisan keluarga yang diasaskan pewaris khususnya ibu mereka dalam mengusahakan pembuatan dan pemasaran songket. Sebelum mengambil alih perusahaan warisan keluarga, mereka telah terlibat dalam bidang keusahawanan selama beberapa tahun bagi menambah pengalaman. Misalnya, Puan Idah bercita-cita untuk menjadi seorang usahawan wanita selepas ibunya menumpukan kepada proses pembuatan songket sahaja yang terletak berhampiran dengan rumahnya. Situasi tersebut merupakan peluang yang beliau nantikan untuk menjadi seorang usahawan wanita yang berjaya. Namun, terdapat juga usahawan wanita yang bukan dilahirkan dalam kalangan keluarga berniaga tetapi mewarisi perniagaan selepas berkahwin. Peluang seperti ini memberi kelebihan kepada mereka bagi mengembangkan perniagaan yang diwarisi kerana telah mempunyai pengalaman dalam keusahawanan. Pada masa yang sama, budaya berniaga dalam keluarga dapat dipertahankan walaupun terdapat dalam kalangan pewaris perniagaan kurang berminat untuk menerajui perniagaan dan menyerahkan kepada si isteri untuk menguruskannya. Penemuan tentang budaya warisan dapat diteliti ke atas informan kajian iaitu Kak Dah yang mewarisi perniagaan batik warisan keluarga selepas berkahwin.

Abis je SPM...saya kijo (kerja) di kedai jual batik di Kota Bharu... adalaa dale tiga ke empat tahun jugak...lepas kahwin. Rupanya suami ado mewarisi perniagaan dari keluarga dio...jual batik...tapi...suami dok (tak) minat nak uruskan...sebab saya pernah kijo di kedai batik sebelum ni, suami suruh saye jago kedai tu...sampai loni...saye jago semo sendiri sebab suami tak suka pakai pekerja...lebih senang urus sendiri. (Kajian lapangan pada 2015 bersama Kak Dah) 
Hal ini menunjukkan informan mewarisi perusahaan batik daripada bapa mentua selepas beliau berkahwin kerana suami atau ahli keluarga lain tidak berminat untuk menguruskan perusahaan dan menyerahkan perusahaan batik keluarga mereka kepada informan. Selain itu, bekerja sendiri lebih menjamin masa depan berbanding dengan bekerja makan gaji. Alasan tersebut merupakan sebab wanita sanggup berhenti kerja walaupun telah mempunyai pendapatan yang tetap pada setiap bulan. Pada masa yang sama, mewarisi perusahaan keluarga selepas berkahwin menjadi pemangkin kepada penglibatan wanita dalam bidang keusahawanan. Seorang informan iaitu Puan Na yang merupakan pengusaha dan penjual batik sejak 26 tahun yang lalu menyatakan seperti berikut:

Breti kijo (Berhenti kerja) sebagai cikgu semata-mata nok masuk dale keusahawanan tok rajin nyesal sebab...nok ambil alih perniagaan hok diwarisi dari ayah mentua saye. Bagi sayela, nego (berniaga) ni lebih terjamin sikit maso depan pastu lebih puas hati. (Kajian lapangan pada 2015 bersama Puan Na)

Informan berpendapat bahawa berniaga lebih menjamin masa depan yang cerah dan memberi kepuasan kepada dirinya. Keputusan untuk menceburi bidang ini dilakukan berdasarkan perasaan minat yang ada dalam diri sejak sekian lama. Semasa bekerja sebagai guru, beliau sangat aktif berniaga secara kecil-kecilan di sekolah yang dilakukan secara sukarela. Berniaga menurut beliau memberi kepuasan yang sangat tinggi nilainya jika mempunyai kemahuan di dalam diri.

\section{Situasi semasa}

Situasi semasa dalam kajian ini bermaksud wanita yang terlibat dalam perusahaan batik dan songket berlaku tanpa diduga atau tidak dijangka. Walaupun dilahirkan dalam keluarga yang mengusahakan perniagaan, mereka tidak merancang untuk terlibat dalam aktiviti perniagaan. Namun, faktor kesihatan pengusaha terdahulu yang kurang memuaskan menjadi permulaan kepada pembentukan usahawan wanita yang berlaku secara tidak sengaja. Di samping itu, pengaruh perniagaan warisan keluarga juga menjadi alasan utama kepada pembabitan wanita dalam bidang perniagaan. Bagi anak perempuan tunggal pula, mereka tidak mempunyai pilihan lain selain daripada memikul tanggungjawab mengambil alih perniagaan keluarga supaya kemahiran berniaga yang diwarisi sentiasa berterusan. Apabila kesihatan pengusaha asal tidak mengizinkan serta tidak dapat menguruskan perniagaan dengan baik, anak perempuan dipertanggungjawabkan untuk mewarisi perniagaan warisan keluarga. Informan menyatakan: 
Mok (Mak) slalu sakit-sakit...buat saye secara kebetulan terlibat dale (dalam) perniagaan. Keadaan mok ni beri peluang pado saye untuk ambil alih perniagaan dari mok. Adik-beradik lain pun tak minat nak ambil alih sebab ado perniagaan sendiri. (Kajian lapangan pada 2015 bersama Puan Zita)

Keadaan kesihatan pewaris (ibu) menjadi alasan untuk mengambil alih perniagaan warisan keluarga. Walaupun tidak merancang untuk menjadi usahawan, kekangan tersebut menyebabkan informan terpaksa mengambil alih perniagaan tersebut kerana adik-beradik yang lain telah memiliki perniagaan masing-masing.

\title{
Pendedahan dalam perniagaan
}

Pendedahan dalam perniagaan merupakan pengenalan awal oleh pewaris kepada usahawan wanita mengenai perusahaan batik dan songket. Pengenalan awal membolehkan individu mendapat pengalaman sebagai pendedahan dalam bidang urus niaga keluarga. Seseorang individu sering terdedah dengan suasana aktiviti jual beli di sekeliling sehingga menyebabkannya tertarik dan cuba memasuki bidang tersebut sebagai usahawan. Keadaan yang berlaku secara berterusan memberi motivasi kepada mereka untuk memiliki perniagaan milik sendiri pada masa hadapan. Kebanyakan golongan wanita mendapat pendedahan dalam perniagaan melalui pewaris mereka yang telah berniaga sejak sekian lama. Kaum ibu terutamanya yang mempunyai anak yang masih kecil, kebiasaannya akan membawa anak-anak ke tempat mereka berniaga. Hal ini berterusan sehinggalah anak-anak meningkat dewasa dan mula memahami keadaan yang berlaku di sekeliling mereka. Wanita yang dilahirkan dalam keluarga yang terlibat dalam keusahawanan mempunyai lebih pengalaman berbanding dengan mereka yang memulakan perniagaan tanpa bergantung kepada perusahaan keluarga. Informan menyatakan seperti berikut:

\begin{abstract}
Perniagaan warisan keluarga ni bui (beri) pengalame (pengalaman) pado saye pasal nego (berniaga) ni hok patut pertahan dari satu generasi ke generasi. Supaya jadi kebanggaan pado generasi akan datangla. Saye setuju sangatla...kemahiran dan pengalaman hok buleh (boleh) dari perniagaan keluarga buleh bui kelebihan pado saye untuk rancang hala tuju perniagaan hok diwarisi pada masa depe (depan). (Kajian lapangan pada 2015 bersama Ani)
\end{abstract}

Informan menjelaskan individu yang dilahirkan dalam keluarga yang menjalankan perniagaan warisan keluarga, didapati lebih banyak terdedah dengan aktiviti keusahawanan sejak dari awal kehidupan. Beliau juga dapat 
memahami tugas dan peranan pengasas perniagaan (ibu) yang dilakukan sebelum ini bagi mengembangkan perniagaan yang diusahakan. Kerjaya keusahawanan boleh dipengaruhi oleh latar belakang pekerjaan ibu bapa sebagai seseorang usahawan. Faktor keluarga juga memainkan peranan dalam menggalakkan kredibiliti keusahawanan sebagai satu kerjaya. Selain itu, wujudnya perkaitan yang agak kuat di antara kerjaya keluarga dengan pemilihan kerjaya usahawan. Dorongan untuk menjadi seorang usahawan wanita turut berkait rapat dengan inspirasi daripada individu lain yang telah berjaya. Kejayaan ini menjadi pendorong kepada mereka yang berkeinginan untuk menjadi seorang usahawan yang berjaya (Hisrich dan Peters 1998).

\section{Pembudayaan Nilai Agama}

Aktiviti keusahawanan merupakan satu pekerjaan yang sinonim dalam masyarakat yang telah wujud sejak zaman Nabi Muhammad SAW lagi. Agama Islam juga menuntut umatnya melakukan aktiviti jual beli sebagai sumber pendapatan. Pelbagai usaha telah dilakukan oleh pihak kerajaan bagi menggalakkan penglibatan wanita dalam perniagaan seperti Program Inisiatif Meningkatkan Taraf Kehidupan Isi Rumah Berpendapatan Rendah. Program pembangunan wanita ini membolehkan usahawan wanita menjana pendapatan dengan berterusan yang diterajui Kementerian Pembangunan Wanita, Keluarga dan Masyarakat dengan kerjasama Jabatan Pembangunan Wanita. Inisiatif yang dilaksanakan kerajaan ini bertujuan membolehkan golongan wanita memiliki pekerjaan yang mampu memberi keuntungan yang tinggi kepada mereka. Pembudayaan nilai agama yang dibincangkan dalam konteks kajian ini adalah dari segi sunnah, peluang bersedekah dan membina hubungan silaturahim dalam kalangan usahawan wanita yang lain.

\section{Sunnah}

Keusahawanan merupakan satu pekerjaan yang amat popular kerana boleh memberi pendapatan yang tinggi kepada individu yang menceburinya. Bidang keusahawanan ini adalah bidang yang dipandang tinggi dalam agama Islam kerana Nabi Muhammad SAW juga merupakan seorang usahawan. Banyak manfaat diperoleh sekiranya menjadikan bidang ini sebagai satu kerjaya. Islam juga menyatakan sumber pendapatan yang diberkati ialah melalui bidang keusahawanan iaitu mewakili sembilan per sepuluh punca rezeki dalam pekerjaan. Oleh itu, usahawan yang menjalankan aktiviti jual beli dengan amanah akan memperoleh ganjaran keuntungan dalam perniagaan yang dijalankan. 
Ganjaran keuntungan akan diterima apabila menceburi keusahawanan yang merupakan sunnah Nabi Muhammad SAW. Perusahaan batik dan songket pula mempunyai nilai yang tinggi di pasaran. Ganjaran dalam bentuk keuntungan ini bakal dinikmati oleh usahawan wanita yang bersikap jujur dan amanah semasa menjalankan aktiviti jual beli. Situasi yang dihadapi oleh informan mengenai sunnah ialah:

Dale nego ni...saye sokmo (selalu) jujur amanah dengan customer hok mari beli...kalu tak jujur gak, customer lari. Alhamdulillah...rezeki dale nego (berniaga) ni meme tak putus-putus...ni semua ganjaran Allah bagi. Saye percaya kalu kito jujur dengan diri sendiri...Allah pun bagi lebih rezeki pado kito. (Kajian lapangan pada 2015 bersama Puan Na)

Ganjaran keuntungan menjadi tarikan kepada informan untuk mengusahakan perniagaan. Ganjaran yang diterima lebih banyak apabila selalu mengamalkan sikap jujur dan amanah. Selain itu, rezeki dalam berniaga bergantung pada Allah SWT. Apabila usahawan wanita jujur dengan diri sendiri, Allah SWT akan memberikan rezeki dalam bentuk keuntungan kepada mereka. Mereka percaya sikap baik semasa mengusahakan perniagaan akan dibalas dengan ganjaran keuntungan oleh Allah SWT. Ganjaran keuntungan ini boleh diperoleh setelah pelanggan berminat terhadap produk yang dijual dan pelanggan tersebut akan mengulangi pembelian ke atas produk yang disukai pada masa hadapan.

\section{Peluang bersedekah}

Peluang bersedekah kepada orang lain dalam kajian ini merupakan contoh yang baik dilakukan usahawan untuk menjadi ikutan kepada usahawan wanita yang lain. Perniagaan yang dilakukan dengan bersungguh-sungguh dan ikhlas dianggap sebagai sebahagian ibadah kepada Allah SWT. Niat yang ikhlas semasa menjalankan urus niaga bagi memperoleh keuntungan sesungguhnya akan dibalas dengan kebaikan seperti keuntungan yang diperoleh dari hasil jualan produk. Bagi mensyukuri lebihan rezeki yang diterima, mereka mendapat peluang bersedekah kepada orang yang lebih memerlukan. Peluang sebegini perlu direbut dengan sebaiknya oleh usahawan wanita sebagai contoh yang baik kepada anggota masyarakat.

Di sebalik menyumbang kepada pendapatan keluarga usahawan wanita itu sendiri, mereka juga berpeluang melakukan kerja-kerja amal seperti yang dianjurkan agama Islam dengan berbuat baik kepada manusia yang lain. Contoh baik yang ditunjukkan mampu menarik minat wanita yang mempunyai niat 
menjadikan kegiatan keusahawanan sebagai pekerjaan bagi menyara keluarga mereka. Menurut informan iaitu Puan Non:

Ada masanya saye buat diskaun masa jual songket...bagi diskaun pado ore (orang) hok beli tu. Saye anggap mace bui (beri) sedekah...sebab ada ore tak mampu beli songket... ada ore mampu beli... ore lain tengok ni. Jadi contohlah pado ore lain hok nak jadi usahawan wanita jugak. Agama kita pun suruh kita banyok bersedekah ke ore. (Kajian lapangan pada 2015 bersama Puan Non)

Sesetengah orang tidak mampu membeli songket kerana faktor harga. Oleh itu, dengan mengadakan potongan harga ataupun diskaun pada masa tertentu, mereka mampu mendapatkan kain songket pada harga mampu milik. Sementara itu, wanita lain yang melihat tindakan membudayakan nilai agama dalam perniagaan akan tertarik untuk menceburi bidang keusahawanan. Semasa mengusahakan perniagaan songketnya, informan sentiasa membuat potongan harga bagi setiap kain songket yang dijual. Potongan harga tersebut dibuat bertujuan memberi peluang kepada golongan berpendapatan sederhana supaya mereka juga dapat membeli dan memakai kain songket. Situasi ini dianggap sebagai satu sedekah ataupun amal jariah dalam berniaga seperti yang dituntut dalam agama Islam. Maka, informan bersetuju peluang bersedekah yang dimiliki dalam kalangan usahawan batik dan songket mampu menarik perhatian wanita lain untuk menceburi aktiviti keusahawanan.

\section{Membina hubungan silaturahim}

Aspek membina hubungan silaturahim merupakan pembentukan jaringan perniagaan dalam kalangan usahawan wanita yang menjalankan perniagaan. Jaringan perniagaan ialah memiliki kenalan perniagaan di antara usahawan wanita dengan usahawan wanita lain yang mengusahakan perniagaan yang sama. Walaupun mengusahakan perniagaan yang sama, usahawan wanita yang terlibat dapat bertukar-tukar pendapat bagi memajukan perniagaan yang dijalankan. Mereka juga boleh mengadakan usaha sama bagi mempelbagaikan jualan produk ke arah mendapatkan keuntungan yang tinggi. Di samping itu, agama Islam turut menggalakkan umatnya membina hubungan silaturahim walaupun ketika terlibat dalam sektor pekerjaan. Alasan informan terlibat dalam keusahawanan seperti berikut:

Saye lamo doh dale bidang ni...lebih 20 tahun ambil alih kedai songket dari mok...sebab takda adik-beradik lain...banyok doh kenal saingsaing (kawan-kawan) hok jual songket ni...tokey-tokey (tauke-tauke) 
besar pun saye kenal...mudoh buat networking denge ore (orang) dale bidang samo... sene (senang) nak pasarkan songket buatan sendiri nanti. (Kajian lapangan pada 2015 bersama Puan Ma)

Peluang berkenalan dengan usahawan wanita yang lain boleh mewujudkan hubungan dalam bentuk jaringan perniagaan. Jaringan perniagaan yang terjalin antara sesama usahawan wanita membolehkan perniagaan yang dijalankan dapat bertahan dalam jangka masa yang lama. Sepanjang 20 tahun mengusahakan perniagaan tersebut, responden banyak mengadakan kerjasama dengan usahawan wanita yang lain sebagai jaringan perniagaan untuk menambahkan kenalan perniagaan yang luas pada masa hadapan. Amalan pembudayaan nilai agama mempunyai pengaruh yang positif di dalam pembangunan ekonomi masyarakat Islam di rantau Asia (Syed Hussein 1972). Peranan agama ini adalah sangat signifikan sama ada sebagai pembentuk personaliti, pendorong dan pengawal pemikiran serta tingkah laku dalam aktiviti keusahawanan (Solahuddin dan Che Zarrina 2012, 39). Usahawan yang berpegang kepada prinsip Islam juga harus melaksanakan keadilan, kebajikan, memberi sedekah dan tidak melakukan penipuan dalam perniagaan yang dijalankan (Syed Omar 2012). Hasil keuntungan yang diperoleh melalui aktiviti jual beli juga membolehkan usahawan wanita bersedekah kepada golongan yang memerlukan bagi menjadi contoh ikutan kepada usahawan wanita yang lain. Usahawan wanita yang menjalankan perniagaan turut berpeluang berkenalan dan tolongmenolong antara satu sama lain bagi memudahkan jaringan dalam perniagaan (Wan Sabri 2001).

\section{IMPLIKASI DAN CADANGAN}

Hasil kajian berkenaan pembentukan usahawan kraf tangan menunjukkan terdapat elemen tolakan dan tarikan dalam menjadikan usahawan ini terlibat dengan perniagaan batik dan songket. Elemen tolakan bermaksud mereka terpaksa menceburi bidang keusahawanan seperti situasi semasa perniagaan warisan keluarga. Keterpaksaan ini menyebabkan mereka terlibat secara langsung dan kekal menguruskan perniagaan tersebut. Manakala faktor tarikan merupakan faktor tertentu yang menarik minat usahawan untuk terlibat dengan perniagaan seperti mengikut sunnah, bersedekah dan membina hubungan silaturahim. Perkara ini turut dibincang oleh Shapero dan Sokol (1982) serta Subrahmaniam dan Mohammed (2018) mengenai faktor pencetus kepada keterlibatan seseorang dalam bidang keusahawanan. Sunil dan Harold (2018) menegaskan terdapat faktor dalaman dan luaran yang membentuk individu menjadi usahawan. Kajian ini mendedahkan pengalaman dan semangat yang 
diperoleh daripada keluarga menjadi pendorong untuk menyambung warisan keluarga atau mencuba perniagaan batik dan songket.

Penemuan tersebut memberi impak bahawa wanita mampu memberi sumbangan kepada pertumbuhan ekonomi dari segi ekonomi keluarga, ekonomi lokal dan ekonomi negara. Selain itu, penglibatan wanita dalam keusahawanan menunjukkan pemerkasaan wanita melalui modal manusia dan modal sosial. Pemerkasaan ini bukan sahaja kepada individu (wanita) tersebut, tetapi pemangkin kepada kewujudan peluang pekerjaan, inovasi dan sumbangan ketara ekonomi sekitarnya. Peningkatan kaum wanita dalam dunia keusahawanan menjadi satu fenomena yang menjadi penyelesaian kepada kemunculan teknologi maklumat dan globalisasi ekonomi. Hal ini juga disentuh oleh Ascher (2012) bahawa keperluan kepakaran wanita dalam sesebuah industri mendorong mereka menceburi sesebuah bidang khusunya keusahawanan. Tambahan lagi, wanita kini telah memiliki tahap pendidikan tinggi sesuai dengan kemahiran yang diperlukan dalam sesebuah industri (Agarwal 2019).

Selain itu, usahawan kraf tangan wanita turut mengakui industri batik dan songket mempunyai potensi dalam pasaran dan mampu menjana pendapatan yang lumayan kepada mereka. Sumbangan industri batik dan songket adalah signifikan terhadap pencapaian taraf hidup yang lebih baik kepada usahawan wanita yang terbabit. Oleh yang demikian, peranan institusi dan kerajaan berupaya memberi peluang kepada wanita untuk terlibat secara aktif menerusi keusahawanan kraf tangan. Program yang boleh dilaksanakan ialah pembangunan satu daerah dan satu industri terhadap golongan wanita. Program ini bertujuan untuk membangunkan tenaga kerja dan pemantapan kemahiran, pembangunan pengeluaran produk dan sistem pengeluaran, penambahbaikan prasarana pengeluaran, penyertaan di dalam aktiviti promosi dan pasaran serta pembangunan produktiviti dan kualiti. Selain itu, teknik dan sentuhan inovasi baharu yang digunakan dalam menghasilkan batik dan songket memberi nafas baharu untuk penjenamaan semula tanpa menghilangkan karya asli kraf tersebut. Kalyani dan Mounika (2016) telah menghuraikan tentang pengekalan sesuatu industri mikro untuk memastikan penghasilan produk tradisional terus berada di pasaran sebagai warisan dan produk pelancongan. Hal ini kerana, batik dan songket bukan sahaja untuk pakaian orang Melayu tetapi juga telah diperluaskan fungsinya. Batik dan songket kini telah dimartabatkan sebagai produk warisan negara yang bernilai tinggi kepada ekonomi negara (Hanitahaiza, Nor Laila dan Ariff 2012).

Apa yang penting, pembentukan usahawan wanita perlu diiktiraf oleh pembuat dasar terutamanya di kawasan tempatan yang menyumbang kepada 
pembentukan usahawan kecil tempatan baharu. Pengiktirafan ini dapat meningkatkan keupayaan kawasan lokal yang membawa kepada pertumbuhan ekonomi kawasan tersebut, seterusnya membantu usaha pemerintah untuk mengurangkan kemiskinan.Sebagai negara yang sedang membangun, Malaysia mempunyai komitmen yang tinggi untuk mencapai matlamat Sustainable Development Goals (SDGs) khususnya dalam pemerkasaan kaum wanita. Pembinaan kapasiti wanita termasuk meningkatkan produktiviti dan inovasi usahawan wanita menjadi elemen penting kepada pemerintah sebagai pelan dan polisi pembangunan sosioekonomi.

Kajian pembentukan usahawan kraf tangan wanita akan lebih menarik apabila dihuraikan mengenai pembiayaan kredit daripada pemerintah dan badan berkaitan untuk meneruskan kelangsungan industri kraf tangan batik dan songket kepada usahawan wanita. Selain itu, kajian lanjut seperti sejauh mana pengekalan usahawan kraf tangan wanita dalam mendepani cabaran revolusi industri 4.0 perlu diambil kira. Responden kajian juga boleh diperluaskan kepada usahawan kraf tangan lain seperti pengusaha tanah liat dan ditambah bilangan responden. Skop kawasan kajian juga boleh diperluaskan kepada negeri lain untuk melihat perbezaan seperti pantai Timur dan pantai Barat. Aspek sejarah perusahaan batik dan songket juga perlu diteliti untuk mengetahui faktor yang menyebabkan keusahawanan batik dan songket ini lebih sinonim diusahakan oleh golongan wanita, khususnya di pantai Timur. Oleh itu, aspek sejarah perkembangan batik dan songket di Malaysia perlu diberi perhatian yang sewajarnya untuk dikaji dan diteliti sehingga industri ini dikenali sebagai industri kotej dalam kalangan wanita yang mencari sumber pendapatan sampingan. Beberapa cadangan di atas boleh dipertimbangkan sebagai kajian akan datang supaya dapatan berkaitan usahawan kraf tangan wanita lebih meluas.

\section{PENUTUP}

Dalam menghadapi arus globalisasi, peranan dan sumbangan wanita adalah signifikan, bukan sahaja kepada peningkatan pendapatan keluarga, bahkan kepada ekonomi negara. Selaras dengan hasrat dunia yang ingin memperkasakan kedudukan wanita, peluang dan ruang untuk kaum wanita terlibat dalam pelbagai bidang perlu diterima dengan terbuka oleh semua pihak. Pada hari ini, jelas menunjukkan penglibatan wanita dalam pelbagai sektor ekonomi sangat relevan. Misalnya, dalam bidang kejuruteraan, pembinaan, pemprosesan dan pembuatan serta bidang perkhidmatan disertai oleh kaum wanita. Perkara ini menunjukkan gender bukanlah satu halangan untuk seseorang berjaya dan berkerjaya. 
Kajian ini juga telah membuktikan, kaum wanita boleh dibentuk menjadi usahawan melalui penerapan sikap, warisan keluarga dan pembudayaan nilai agama. Pembentukan usahawan batik dan songket dalam kalangan wanita secara tidak langsung meningkatkan martabat industri kraf tangan negara yang menjadi nilai dan budaya masyarakat Malaysia khususnya.

\section{PENGHARGAAN}

Pengkaji mengucapkan terima kasih kepada Jawatankuasa Penyelia iaitu Dr. Nor Hayati Sa'at, Dr. Roslina Ismail dan Profesor Madya Dr. Wan Ibrahim Wan Ahmad atas bimbingan untuk menghasilkan makalah ini. Tidak dilupakan kepada Kementerian Pendidikan Tinggi dan Universiti Malaysia Terengganu atas tajaan dan peluang yang diberikan untuk menyambung pengajian. Walau bagaimanapun, sebarang kelemahan dalam makalah ini merupakan tanggungjawab pengkaji.

\section{RUJUKAN}

Agarwal, J. 2019. Women entrepreneurship and innovations: Evidence from India. Research Journal of Social Science \& Management 8(10): 64-68.

Ascher, J. 2012. Female entrepreneurship: An appropriate response to gender discrimination. Journal of Entreprenuership, Managemant and Innovation 8(4): 97-114. https://doi.org/10.7341/2012847

Azlizan Talib, Mohd Nazaruddin Yusof, Zainal Md Zan and Kamarudin Ngah. 2017. E-bisnes, pemangkin penyertaan kaum wanita dalam keusahawanan luar bandar. Journal of Advanced Research in Business and Management 9(1): 54-66. https://doi.org/10.32890/9789670876436

Creswell, J. and V.L.P. Clark. 2007. Designing and conducting mixed methods research. Thousand Oaks: Sage.

Dahlan Ibrahim. Keusahawanan Malaysia: Keusahawanan Islam. Petaling Jaya: Prentice Hall.

Drucker, P. 1964. Innovation and entrepreneurship. New York: Harper \& Row Publisher Inc.

Faradillah Iqmar Omar, Samsudin A. Rahim dan Nur Ajeerah Othman. 2017. Penggunaan internet dalam kalangan usahawan wanita: Akses, kemahiran dan motivasi. Jurnal Komunikasi 33(3): 21-36. https://doi.org/10.17576/JKMJC-2017-3303-02

Hanitahaiza Hairuddin, Nor Laila Md. Noor, Ariff Md Ab Malik. 2012. Why do microenterprise refuse to use information technology: A case of batik microenterprise in Malaysia. Procedia-Social Behavioral Science 57: 494-502. https://doi.org/10.1016/j.sbspro.2012.09.1216 
Haziyah Hussin. 2006a. Aktiviti seni dan budaya lampau: Penghasilan dan penggunaan tekstil di Alam Melayu dari sudut sejarah. Jebat 33: 96-10.

2006b. Warisan aktiviti penghasilan batik dan songket di Semenanjung Malaysia. Jurnal Arkeologi Malaysia 19: 37-48.

Hisrich, R.D. and M.P. Peters. 1998. Entrepreneurship. Boston: Irwin/McGraw Hill.

Ibnu Khaldun. 1904. The muqaddimah. New Jersey: Princeton University Press.

Ivana, F., K. Jalena and T. Ana. T. 2017. Motivational factors: Drivers behind women entrepreneurs' decision to strat an entrepreneurial venture in Croatia. Scientific Annals of Economics and Business 64(3): 339-357. https://doi.org/10.1515/ saeb-2017-0022

Jhingam, M.L. 1979. The economic of development and planning. 12th ed. New Delhi: Vikas Publicity House.

Jyoti, A. 2019. Women entrepreneurship and innovations: Evidence from India. Research Journal of Social Science \& Management 8(10): 64-68.

Kalpana, R.A. 2016. The role of women entrepreneurs in establishing sustainable development in developing nations. World Review of Business Research 6(1): 161-178.

Kalyani, A.L.N.S. and G.S. Muonika. 2016. Factors influencing female entrepreneurship. Anveshana's International Journal of Research Regional Studies, Law, Social Sciences. Journalism and Management Practices 1(8): 54-60.

Kirzner, I.M. 1979. Perception, opportunity and profit: Studies in the theories of entrepreneurship. Chicago: University of Chicago Press.

Laderman, C. 1982. Putting Malay women in their place. In Women of Southeast Asia, ed. P. Esterik. Monograph series on Southeast Asia, occasional paper no. 9. Ilinois: Center for Southeast Asian Studies, Northern Ilinois University.

Marshall, C. and G. Rossman. 1999. Designing qualitative research. 3rd ed. London: Sage.

Mohd Maliki Kamarul Zaman and Norasmah Othman. 2018. Amalan pengurusan perniagaan usahawan wanita Felcra Berhad. Jurnal Inovasi Perniagaan 3(1): $1-21$.

Mohd Mokhtar and Wan Nur Syahida Wan Ismail. 2012. Marketing strategies and the difference level of sales and profits performance of the batik SMEs in Malaysia. International Journal of Business and Management 7(23): 96-111. https://doi.org/10.5539/ijbm.v7n23p96

Mohd Shaladdin Muda and Muhammad Abi Sofian Abd Halim. 2011. Usahawan kraf di Malaysia: Analisa laluan terhadap perhubungan inovasi produk, komitmen perniagaan dan perkembangan perniagaan. Prosiding PERKEM VI 2: 208-217.

Nik Azma Nik Day. 2015. Perkembangan industri kraf tangan dan kesannya kepada ekonomi di negeri Kelantan. Projek Sarjana Muda, Fakulti Seni Gunaan dan Kreatif, Universiti Malaysia Sarawak.

Noor Fzlinda Fabeil, Khairul Hanim Pazim, Kamarul Mizal and Juliana Langgat. 2014. The orientation of handicraft entrepreneurs in Sabah: Their personality characterictics and motivations. Paper presented at the 2nd ASEAN Entrepreneurship Conference. Shangri-La Rasa Sayang Resort, Pulau Pinang Malaysia, 17 May. 
Noor Haslina Mohamad Akhir and Normaz Wana Ismail. 2015. Permasalahan dalam pembangunan industri batik di Terengganu. Prosiding PERKEM 10: 239-246.

Nor Aini Haji Idris. 2010. Wanita dalam perniagaan pasar: Kajian kes peniaga kecil wanita di Kelantan. In Himpunan makalah wanita dan pembangunan di Malaysia - Satu kesinambungan: Menyusuli perubahan selama empat dekad, ed. Jamilah Ariffin. Petaling Jaya: MPH Group Publishing.

Nor Aini Idris. 2003. Daya saing usahawan wanita Melayu menghadapi cabaran globalisasi. Paper presented at Prosiding persidangan kebangsaan: Cabaran pembangunan dilema persekitaran. Pusat Pengajian Sosial, Pembangunan dan Persekitaran, Universiti Kebangsaan Malaysia, Selangor. 12-13 September.

Nor Azira Ayob, Sity Daud and Muhamad Takiyuddin Ismail. 2016. Modal insan, daya saing dan prestasi usahawan wanita di Malaysia: Analisis kualitatif usahawan wanita bumiputera di Melaka. Malaysian Journal of Society and Space 12(10): $56-67$.

Nor Azira Ayob, Sity Daud and Nurul Nadia Abu Hasaan. 2018. Prestasi pengusaha wanita: Hasil pembentukan faktor modal insan dan daya saing. Malaysian Journal of Social Science and Humanities 3(3): 173-188.

Norazilawati Abd Wahab and Arba'iyah Mohd Noor. 2013. Kegiatan perusahaan dalam kalangan masyarakat Melayu di Terengganu 1800-1941. Sarjana 28(1): 137-162. https://doi.org/10.22452/sejarah.vol21no1.3

Norwani Mohd. Nawawi. 1994. Malaysian songket. Kuala Lumpur: Dewan Bahasa dan Pustaka.

Nsubili, I. 2019. Start-up motives and challenges facing female entrepreneurs in Tanzania. International Journal of Gender and Entrepreneurship 11(2): 102-119. https://doi.org/10.1108/IJGE-02-2018-0010

Perbadanan Kraftangan Malaysia Cawangan Kelantan. 2015. Senarai usahawan di daerah Kota Bharu, Kelantan. Kelantan: Perbadanan Kraftangan Malaysia Cawangan Kelantan.

Perbadanan Kraftangan Malaysia Cawangan Terengganu. 2015. Senarai usahawan di daerah Kuala Terengganu, Terengganu. Terengganu: Perbadanan Kraftangan Malaysia Cawangan Terengganu.

Rogerson, C.M. 2010. The enterprise of craft: Constraints and policy challenges in South Africa. Acta Academica 42(3): 115-144.

Scott, S. 2000. Prior knowledge and the discovery of entrepreneurial opportunities. Organization Science 11(4): 448-468. https://doi.org/10.1287/orsc.11.4.448 .14602

Shapero, A. and L. Sokol. 1982. The social dimensions of entrepreneurship. In Encyclopaedia of entrepreneurship, eds. C. Kent, D. Sexton and K. Vesper, 72-90. Englewood Cliffs, NJ: Prentice-Hall.

Siti Masayu Rosliah Abdul Rashid and Narimah Samat. 2019. Peranan dan pelaksanaan ICT dalam memperkasakan usahawan wanita luar bandar di Malaysia. Akademika 89(3): 75-88.

Siti Zainon Ismail. 1986. Rekabentuk kraftangan Melayu tradisi. Kuala Lumpur: Dewan Bahasa dan Pustaka. 
Solahuddin Abdul Hamid and Che Zarrina Sa'ari. 2012. Motivasi pencapaian usahawan Melayu: Hubungannya dengan penghayatan agama. Jurnal Pembangunan Sosial 15: 29-45.

Subrahmaniam Muthuraman and Mohammed Al Haziazi. 2018. Pull and push motives for women entrepreneurs in Sultanate of Oman. ZENITH International Journal of Multidisciplinary Research 7(7): 79-95.

Sunil, K. and A.P. Harold. 2018. Motivating factors that influence women entrepreneurs. International Journal of Research in Business Management 6(4): 65-80.

Surat Pekeliling Perkhidmatan Bilangan 1 Tahun 2008. Pemakaian pakaian batik Malaysia oleh pegawai awam pada hari Khamis. Kerajaan Malaysia JPA(S) TT. 193/37 Klt. 5(38).

Syarifah Md Yusof, Abu Bakar Hamed, Raziah Md Tahir and Azizah Othman. 2018. Usahawan wanita Muslim berjaya: Amalan gaya hidup Islam. International Journal of Islamic Studies 3(1): 1-18.

Syed Hussein Alatas. 1972. Modernization and social change: Studies in modernization, religion, social change and development in South-East Asia. Sydney: Angus \& Robertson.

Syed Omar Syed Agil. 2012. Teori, amalan dan perniagaan Islam. Petaling Jaya: Longman Malaysia.

Wan Abdul Kadir Yusoff. 1998. Nilai dan world-view orang Melayu tentang gender. In Gender, budaya dan masyarakat, eds. Rokiah Talib and S. Thambiah, 2-13. Kuala Lumpur: Rancangan Pengajian Gender, Fakulti Sastera dan Sains Sosial, Universiti Malaya.

Wan Sabri Wan Hussin. 2001. Nilai dan etika Islam dalam perniagaan amalan dan tanggapan masyarakat Malaysia. PhD diss., Universiti Malaya.

Zaimah, R. and Sazuani Abdullah. 2017. Tahap keupayaan usahawan dalam perusahaan kecil dan sederhana di Kuala Terengganu. Malaysian Journal of Society and Space 13(4): 117-125. https://doi.org/10.17576/geo-2017-1304-11

Zurinah Tahir, Jalaluddin Abdul Malek, Sivapalan Selvadurai and Yusof Hussain. 2019. Transformasi memajukan industri kecil dan sederhana (IKS) dalam kalangan wanita luar bandar. Malaysian Journal of Society and Space 15(4): 151-162. https://doi.org/10.17576/geo-2019-1504-11 